\title{
Isolation and Identification of Staphylococcus spp. from Bovine Mastitic milk and their Sensitivity to some Antibiotics at Al-Qadissiya Province.
}

\author{
M. I. Shekhan \\ M. A. Al-Rodhan \\ Coll. of Vet. Med./ Univ of Al-Qadissiya
}

\author{
J..K.AL-Janabi \\ Maternity and Children Teaching \\ Hospital Al-Qadissiya
}

\begin{abstract}
This study was designed to detect the Staphylococcal bovine mastitis in AlQadissiyaprovince and then identify the most effective antibiotic that could be used for inhibit the growth of isolated microorganism invitro. Milk samples have been collected from 120 different cows at Al-Hamza, AL- Shenafia, Nufar, Sumar, AL- Saniah , Al- Sedeer and Afak the results showed different bacterial isolates identified in the present study as :S.aureus, S.intermedius ,S. hyicus, S. epidemidis, S. chromogenes, S.cohnii , S. hominis , S. xylosus, S.sciuri, S. simulans, S.saprophyticus in a percentage $(15.74 \%, 6.481 \%, 8.333 \%, 7.87 \%$, $3.703 \%, 4.166 \%, 6.481 \%, 5.092 \%, 4.629 \%, 6.018 \%, 0.462 \%$, ) respectively .The sensitivity test results showed that S.aureus, was more sensitive to Ciprofloxacin in a percentage (91.17\%),CNS (Coagulase Negative Staphylococci) was more sensitive to Oxytetracycline $83.25 \%$,
\end{abstract}

\section{Introduction}

"Mastitis" is "inflammation of mammary gland tissue". Inflammation of the bovine udder is usually caused by infection, mostly by bacteria, Intramammary infections can be accompanied by visible changes of milk , such as clotting and discoloration, and clinical signs of animal such as swelling and discoloration of the udder, fever, anorexia and even death. When signs are discernible with the naked eye, infection has caused clinical mastitis.Laboratory techniques such as measurement of somatic cell count (SCC) and bacteriological culture are needed to detect inflammation and infection. Mastitis is a major concern to dairy producers and the food industry around the world for reasons of farm profitability, food quality and animal and public health(1).Diagnosis of

\section{Material \&Methods}

\section{Samples collection:}

One hundred and twenty cows were examined, milk samples which positive to mastitis according to result of CMT and other from clinical mastitic cows were collected from cows in Al-Qadissiya province as follow : AL- Hamza, ALShenafia ,Nufar, Sumer, AL- Saniah ,AlSedeer, andAfak. Milk samples were collected in sterile tubes ( 2 tubes) for each subclinical forms may be more difficult but is an important part of any herd survey to establish the disease incidence . in addition to bacterial culture of milk ,several indirect tests are employed to ensure the presence of inflammatory exudates and cells in infected milk, such as California mastitis test (CMT) ( 2) .This disease can have an infectious or noninfectious etiology, and the infectious pathogen is the most important ones that frequently due to infection by one and/or the other pathogens, such as bacteria, viruses, Mycoplasma, yeasts and algae (3). Fortunately the vast majority of mastitis is of bacterial origin and just a few of species of bacteria account for most cases, such as, $S$. aureus, E. coli Struberis, Str. dysgalactiae and Str. agalactiae (4).

sample (one for CMT and another for bacteriological test) and aseptic technique used for milk samples collection according to $(8)$.

\section{Bacterial culture and identification:}

All milk samples from clinical mastitis and subclinical mastitis which gave a positive reaction with California Mastitis Test ( AlSyria for veterinary preparation .Syria) were submitted to centrifugation at 3000 
rpm / 15 minute, and the precipitate was cultured on :Blood Agar ,Nutrient Agar and MacConky Agar ,all the Petri plate that contain this agars were incubated at 37 $\mathrm{C}^{\circ}$ for 24 - 48hrs (6)Diagnosis depend on morphological character \& cultural character (9), then followed by examination with gram stain, after that the colonies were subcultured on selective and differential media according to the type of isolated bacteria then incubated at $37 \mathrm{C}^{\circ}$ for $24-48$ hrs. The biochemical test used for diagnosis of staphylococcus spp. were include:

- Catalase Test, Oxidase test, Coagulase Test, Urease Test, Heamolysis on blood agar , Gelatin Liquefaction Test ( Gelatinase ), Voges - Proskauer Test , Nitrate reduction Test , Sugar Fermentation Test ( Mannitol, Lactose , Mannose , Xylose ,Trehalose , Sucrose , Maltose ) according to the method of ( 7 ,8, 9).Production of pigment in Mannitol salt agar and in ( Staph 110 media) (LAB -

\section{Results and discussion}

The result showed in Staphylococcus aureus was the most isolated bacteria in percentage $15.74 \%$ in (table 1) may Due to its contagious nature it has become a major udder pathogen in many parts of the world. It may cause both clinical and sub-clinical mastitis (11), the higher percentage of $S$. aureus isolates in this study was agree with a results of (12). The result of CNS in this study include S.intermedius, S. hyicus, $S$. epidemidis, S. chromogenes, S.cohnii, $S$. hominis, S. xylosus, S.sciuri, S. simulans , S.saprophyticus in a percentage of $(6.481 \%, 8.333 \%, 7.87 \%, 3.703 \%$, $4.166 \%, 6.481 \%, 5.092 \%, 4.629 \%$, $6.018 \%, 0.462 \%$ ) respectively (table 1).The results of (S. hyicus , $S$. epidermidis, S. hominis, S.sciuri )in this study was in agreement to the result of (13) who isolates these bacteria from bovine mastitis in a percentage $(6.06 \%, 9.1 \%$, $6,06 \%, 3.03 \%)$, (14) was agree with our result for S.cohnii in a percentage,5\%. ( 15)was isolated $S$. chromogenes in a percentage $2.152 \%$ which was closed with our result . The result of $S$. simulans was
U.K) MAST STAPHTM: ( Mast Group Ltd , USA)API Staph ( biomerioux, France).

\section{Sensitivity test:}

The sensitivity was done according to the procedure of (10) and the following antibiotic were used (Streptomycin $10 \mathrm{mcg}$, Erythromycin $15 \mathrm{mcg}$, Sulphamethaxazole - Trimethoprim 25mcg (1.25/23.75mcg) , Ampicillin 10mcg, Gentamicin $10 \mathrm{mcg}$, Ciprofloxacin 5mcg, Tetracycline $30 \mathrm{mcg}$ ,Oxytetracycline $30 \mathrm{mcg}$, Amoxicillin / Clavulanic cid $30 \mathrm{mcg}(20 \mathrm{mcg} /$ 10mcg)Bioanalyse ${ }^{\circledR} \quad$,Germany).The diameter of the inhibition zone of each antibiotic disc $(\mathrm{mm})$ (the clear area that surround the antibiotic disc including diameter of the disc itself which is free of the bacterial growth ) by using of calibrated ruler and then compared the result with standard diameter of the inhibition zone of the antibiotic as mention in National Committee for Clinical Laboratory Standard( NCCLS).

closed to the result of (16) with a percentage $4.245 \%$ The result of S.xylosus in this study was closed to the result of ( 17) who isolated this bacteria in percentage $3.66 \% . \%$.(18) was closed to our result of S.saprophyticus in a percentage $(0.68 \%, 0.3 \%)$ respectively. (19) was closed with our result for S.intermedius in a percentage $13.9 \%$.(20) disagree with a result of S.hyicus ,S.epidemidis ,S.cohnii ,S.hominis ) in a percentage $(16.5 \%, 1.9 \%$ $, 0.3 \%, 1.9 \%)$ respectively. (21) disagree with our result for S.saprophyticus, $S$. simulans in a percentage $(8.176 \% 1.886 \%)$ respectively , (22) also disagree with our result of S.saprophyticus in a percentage 10.1\%.Among studies isolation of , $S$. chromogenes, S. epidermidis, S. hyicus, and $S$. simulans, seem to be the most common CNS isolated from intra-mammary infections in spite of some variation between herds, countries, and methods used (23). Bovine CNS have traditionally been considered as skin flora opportunists (24).CNS have also been isolated from the cows' environment (25).S. chromogenes was frequently isolated from the teat skin, 
and teat canal, but also from extramammary sites like nares, hair coat and vagina in heifers (26). According to( 27) $S$. cohnii, S. saprophyticus, S.sciuri, and $S$. xylosus, were the most common in the cows' environment (e.g.alfalfa hay, straw and bedding).The variations in the percentage of infection ratio of different CNS may be due to geographical areas and climatic differences. The results of present study showed that there were differences in the percentage of bacterial isolates between villages and township of AlQadissiyaprovince, these differences could be explain may be due to variation in geographical areas and climatic condition, according to the differences in temperature , humidity, environment and nature of society (28) (table 2,3 ). The result of this study for sensitivity test showed that the $S$. aureus was more sensitive to Ciprofloxacin, Erythromycin, Oxytetracycline, Amoxicillin/ Clavulanic acid followed by Sulphamethaxazole/ Trimethoprim then Gentamicin $(91.17 \%$, $88.23 \%, 82.35 \%, 79.41 \%, 73.52 \%$ , $70.58 \%$ ) respectively and less sensitive to Streptomycin $58.82 \%$ and the lower sensitivity to Ampicillin $32.35 \%$ these result was closed to the results of (29) who found that $S$. aureus was more resistance to Ampicillin and $80 \%$ sensitive to Gentamicin.The resistance of bacteria to Ampicillin may caused by random using of this antibiotic (30). The results of sensitivity of Gentamicin was closed to the results of $(31 ; 32)$ while disagree with them in the sensitivity of Ampicillin.(33) was closed with our results of Ciprofloxacin, Gentamicin, Tetracycline, Sulphamethaxazole / Trimethoprim sensitivity with a percentage of ( $100 \%$, $76.88 \%, 71.19 \%, 72.26 \%$ ) respectively while disagree with sensitivity of Ampicillin in a percentage $0 \%$.It has been found that amoxicillin with clavulanic acid are the very efficient in inhibiting the growth of Staph. aureus (34) which was very closed to our results he also reported that $75 \%$ of the Staph. aureus strains were resistant to tetracycline and $6.2 \%$ of the isolated strains were susceptible which was disagree with our results, while (29) mentioned that $58.33 \%$ of isolates susceptible to tetracycline which was closed to our result. (35) found that Staph. aureus was resist to Streptomycin in a percentage $42.9 \%$ which was very closed to our results . (20) was found that Staph. aureus sensitive to Erythromycin in percentage $74.4 \%$ which closed to our results . (36) found the sensitivity of Staph. aureus to Sulphamethaxazole / Trimethoprim was $74.7 \%$ which was very closed to our result . (14) closed with our result in Ciprofloxacin with a percentage $100 \%$ while disagree with our result for Oxytetracycline in a percentage $60 \%$ while the result of Oxytetracycline closed with (30) in $2^{\text {nd }}$ station in a percentage $83.33 \%$.(34) was closed with our result of sensitivity of CNS for Amoxicillin/ Clavulanic acid with a percentage $75 \%$. (20) found that the percentage of sensitivity of CNS for Ampicillin, Streptomycin, Tetracycline was ( $58.2 \%$ $, 62.7 \%, 76.1 \%$ ) respectively which was closed to our results while disagree with our results of Erythromycin 51.4\%. (14) closed to our result of (Ciprofloxacin, Oxytetracycline,Erythromycin,Sulphameth axazole/Trimethoprim) in a percentage $(80 \%, 90 \%, 70 \%, 73 \%)$ respectively also(37) closed to our result of (Oxytetracycline, Erythromycin, Sulphamethaxazole / Trimethoprim, Amoxicillin/ Clavulanic acid , Tetracycline) in a percentage $(77.61 \%$, $71.64 \%, 65.67 \%, 80.6 \%, 71.64 \%)$ respectively while disagree with Gentamicin in a percentage $100 \%$ in table (4) .Resistance to antibiotic mediated most commonly by the production of enzymes that modified the drug e.g $\beta$ - Lactamases Hydrolyse Penicillin other mechanism include decrease the passage in to or increase the efflux of drug from the bacterial cell, modification of the target site so that the antimicrobial bound less effective and by passing of inhibited metabolic pathways as resistance to trimethoprim in many bacteria (38) . 
Table(1): percentage of bacterial isolates

\begin{tabular}{|l|c|}
\hline Bacterial isolates & $\%$ \\
\hline S.aureus & $15.740 \%$ \\
\hline S.intermedius & $6.481 \%$ \\
\hline S. hyicus & $8.333 \%$ \\
\hline S. epidermidis & $7.870 \%$ \\
\hline S. chromogenes & $3.703 \%$ \\
\hline S. cohnii & $4.166 \%$ \\
\hline S. hominis & $6.481 \%$ \\
\hline S.xylosus & $5.092 \%$ \\
\hline S. sciuri & $4.629 \%$ \\
\hline S. simulans & $6.018 \%$ \\
\hline S. saprophyticus & $0.462 \%$ \\
\hline
\end{tabular}


Table (2):Distribution of the Staphylococcus spp. according to regions

\begin{tabular}{|c|c|c|c|c|c|c|c|c|c|c|c|}
\hline Region & $\begin{array}{c}S . \\
\text { aureus }\end{array}$ & $\begin{array}{c}\text { S. } \\
\text { intermedius }\end{array}$ & $\begin{array}{c}\text { S. } \\
\text { hyicus }\end{array}$ & $\begin{array}{c}S . \\
\text { epidermidis }\end{array}$ & $\begin{array}{c}S . \\
\text { chromogenes }\end{array}$ & $\begin{array}{c}S . \\
\text { cohnii }\end{array}$ & $\begin{array}{c}\text { S. } \\
\text { hominis }\end{array}$ & $\begin{array}{c}S . \\
\text { xylosus }\end{array}$ & $\begin{array}{c}S . \\
\text { sciuri }\end{array}$ & $\begin{array}{c}S . \\
\text { simulans }\end{array}$ & $\begin{array}{c}\text { S. } \\
\text { Sapro. }\end{array}$ \\
\hline AL- Hamza & $26.470 \%$ & $5.882 \%$ & $2.941 \%$ & $8.823 \%$ & $2.941 \%$ & $5.882 \%$ & $2.941 \%$ & 0 & $\begin{array}{c}5.882 \\
\%\end{array}$ & $5.882 \%$ & 0 \\
\hline AL- Shenafia & $12 \%$ & $4 \%$ & $4 \%$ & $4 \%$ & 0 & $4 \%$ & $12 \%$ & $12 \%$ & $4 \%$ & $8 \%$ & $4 \%$ \\
\hline Nufar & $14.814 \%$ & $11.111 \%$ & $\begin{array}{c}11.111 \\
\%\end{array}$ & $3.703 \%$ & $11.111 \%$ & $\begin{array}{c}11.111 \\
\%\end{array}$ & 0 & 0 & $\begin{array}{c}7.407 \\
\%\end{array}$ & $7.407 \%$ & 0 \\
\hline Sumer & $9.090 \%$ & 0 & $9.090 \%$ & $9.090 \%$ & 0 & 0 & $9.090 \%$ & 0 & 0 & $9.090 \%$ & 0 \\
\hline AL- Saniah & $10.416 \%$ & $4.166 \%$ & $\begin{array}{c}22.916 \\
\%\end{array}$ & $12.5 \%$ & $2.083 \%$ & 0 & $8.333 \%$ & $4.166 \%$ & $\begin{array}{c}4.166 \\
\%\end{array}$ & $4.166 \%$ & 0 \\
\hline Al- Sedeer & $25.0 \%$ & $7.142 \%$ & 0 & $3.571 \%$ & $3.571 \%$ & 0 & $7.142 \%$ & $7.142 \%$ & $\begin{array}{c}3.571 \\
\%\end{array}$ & $14.285 \%$ & 0 \\
\hline Afak & $11.627 \%$ & $9.302 \%$ & $2.325 \%$ & $9.302 \%$ & $4.651 \%$ & $6.976 \%$ & $6.976 \%$ & $9.302 \%$ & $\begin{array}{c}4.651 \\
\%\end{array}$ & 0 & 0 \\
\hline
\end{tabular}


Table (3): Sensitivity of Staphylococcus Spp. Isolates to Antibiotic

\begin{tabular}{|l|l|c|}
\hline \multirow{2}{*}{$\mathrm{AB}$} & \multirow{2}{*}{ S.aureus } & CNS \\
\cline { 2 - 3 } & & \\
\cline { 2 - 3 } & $\%$ & $\%$ \\
\hline $\mathrm{AM}$ & 23.35 & 56.41 \\
\hline $\mathrm{S}$ & 58.82 & 62.81 \\
\hline $\mathrm{CIP}$ & 91.17 & 74.41 \\
\hline $\mathrm{CN}$ & 70.58 & 73.64 \\
\hline AMC & 79.41 & 70.58 \\
\hline T & 67.64 & 69.67 \\
\hline OT & 82.35 & 83.25 \\
\hline E & 88.23 & 71.93 \\
\hline SXT & 73.52 & 63.16 \\
\hline
\end{tabular}

$\mathrm{AM}=$ Ampicillin, $\mathrm{S}=$ Streptomycin, $\mathrm{CIP}=$ Ciprofloxacin $\mathrm{CN}=$ Gentamicin, , AMC $=$ Amoxicillin $/$ Clavulanic acidT $=$ Tetracycline, $\mathrm{OT}=$ Oxytetracycline, $\mathrm{E}$ =Erythromycin

, SXT = Sulphamethaxazole/Trimeprime

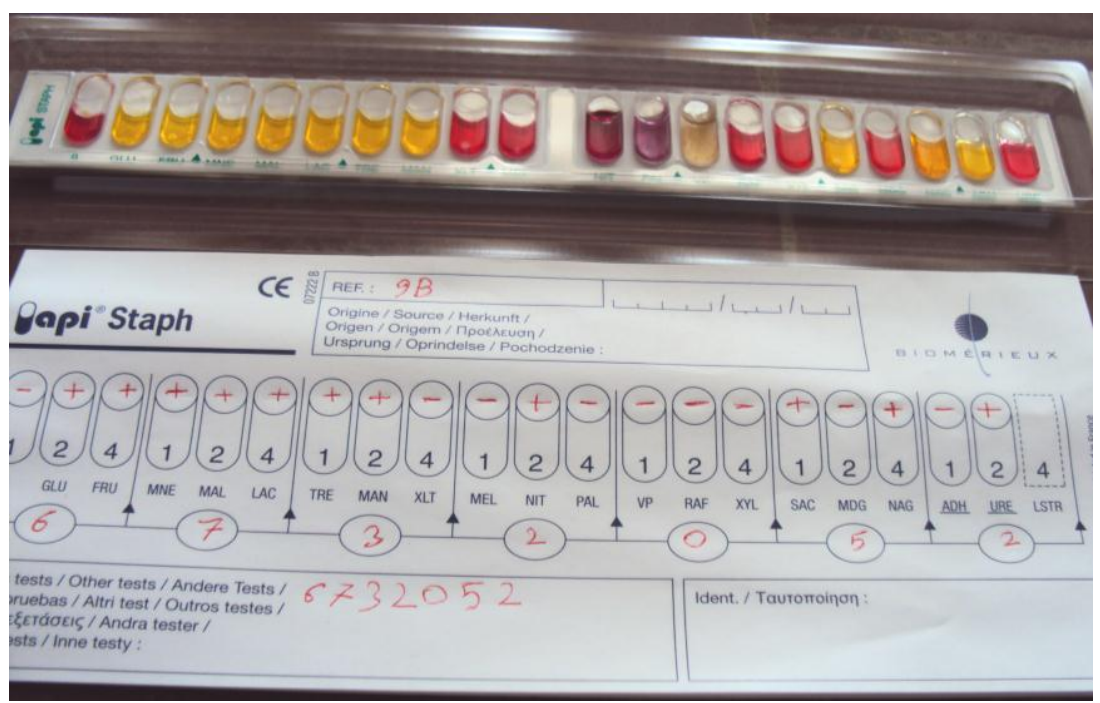

Figure (1) : API Staph

\section{References}

1.Zadoks R. N. (2002): Molecular and mathematical epidemiology of Staphylococcus aureus and Streptococcus uberis mastitis in dairy herds.P.H.D.thesis . Department of Farm Animal Health, Ruminant Health Unit
Faculty of Veterinary Medicine, Utrecht University Netherlands.

2. Hirsh, C.D. and Zee,Y.C. (1999): Veterinary microbiology $.1^{\text {st }}$. Edn., Blackwell Science. PP:43 -48. 
3. Chaneton L.;Tirante L.; Maito J.; Chaves J.; Bussmann LE (2008):Relationship between milk lactoferrin and etiological agent in the mastitic bovine mammary gland. J. Dairy Sci. 91: 18651873.

4. Aouay A; Coppée F; Cloet S; Cuvelier P; Belayew A; Lagneau PE;Mullender C (2008). Molecular characterization of Prototheca strains western part of Poland. Pol. J. Vet. Sci. 9: 191-194.

5. Radostits, O.M.;. Blood, D.C; Gay, C.C. ; Hinchiff K.W. and Handerson J.A.,( 2000). Veterinary Medicine. 9th Ed. W. B. Saunders Company, London, U.K

6. Koneman, E.W.; Allen, S.D.; Janda ,W.M.; Schreckenberger, P.G.(2007): Color Atlas and Text Book Diagnostic Microbiology $.5^{\text {th }}$ Lippincott Willams \& Wilkins .Washington DC. Winn ,Jr. U.S.A.

7. Forbes , B.A.;Sahm,D.F.; Weissfield ,A.S.(2002):Baily \&Scott s, Diag.Microb.11Ed .Mosby.

8. Collee, J. G.; Fraser, A. G.; Marion , B. P. and Simmons, A. (eds)(1996). Mackie and McCaraty Practical Medical Microbiology. $14^{\text {th }}$ ed.Longma n Singapore.Pp:131-149.

9. Macfaddin, J.F. (2000):Biochemical test for identification of medical bacteria $.3 \mathrm{Ed}$ .William and Willkins ,U.S.A.

10. Brooks,G.F.; Butel, J.S. and Morse, S.A.(1998): Jawetz, Melnick and Adelbergs ,Medical Microbiology.21Ed .Appelon and lange, Asimon and Schustero. Calfornia .

11. Sol, J.; Sampimon, O.C., Barkema, H.W. ; Schukken, Y.H.
(2000). Factors associated with cure after therapy of clinical mastitis caused by Staphylococcus aureus. Journal of Dairy Science 83(2), 278-84.

12.El Zubeir,I. E.M. and El Owni O.A.O. (2006):Seasonal Variation of Incidences and Etiological Agents of Bovine Mastitis in Friesian Cattle in Sudan .Research Journal of Animal and Veterinary Sciences, 1(1): 25-29

13. Mahmmoud E.N. and Shamoon G.N. (2009):isolation and identification of coagulase negative staphylococci and detection of virulent factors in bovine mastitis .Iraqi .J.Vet.Sci.vol.23, supplement II .

14. Kaya , O.(2005): Identification and Antimicrobial Susceptibility of Staphylococcus aureus and Coagulase Negative Staphylococci from Bovine Mastitis in the AydÝn Region of Turkey. Turk .J. Vet. Anim .Sci.29:791-796.

15. Gianneechini,R.; Concha,C.; R. Rivero,R., I.;Delucci,I., J.; Moreno ,I.(2002): Occurrence of Clinical and Sub-Clinical Mastitis in DairyHerds in the West Littoral Region in Uruguay. Acta vet. scand. 43(4):221 - 230.

16. Yousif ,A.A.; Al-Dulimy, W.A.G.; Al-Grabawi,M.A.(2008): some aerobic bacterial causes of clinical mastitis in cows and study some causes of treatment failure .Iraqi.Vet.J. 1 ( sup 32 ):148-156

17. Hussein S. A. (2008): Isolation and identification of bacterial causes of clinical mastitis in cattle in Sulaimania region. Iraqi J. Vet.Sci 22 (1):35-41. 
18. Nickerson, S.C.; Owens, W.E. ; Boddie, R.L. (1995): Mastitis in dairy heifers initial studies on prevalence and control. J. of Dairy Sci. 78: 1607-1618.

19. Wattst, J.L. and Washburn, P.J. (1991): Evaluation of the Staph-Zym System with Staphylococci Isolated from Bovine Intramammary Infections. J. Clinic. Micro., 29(1):59-61

20. Edward Malinowski, Anna Klossowska, Michal Kaczmarowski and Krystyna Kuzma.(2003): Prevalence of intramammary infection in pregnant heifers. Bull. Vet. Inst. Pulawy, 47: 165-170

21. Taponen,S.(2008): Bovine mastitis caused by coagulase-negative staphylococci.thesis.P.H.D.

Department of Production Animal Medicine Faculty of Vet. Med. University of Helsinki Finland.

22. Cheng,D.; Zhu,S.Y.; Yin,Z.; Ding,W.; Mu, Z.; Su,Z. and SunH.(2010): Prevalence of bacterial infection responsible for bovine Mastitis. African Journal of Microbiology Research, 4 (11): 1110-1116.

23. Taponen, S.; Simojoki, H.; Haveri, M.; Larsen, H.D. \& Pyorala, S. (2006). Clinical characteristics and persistence of bovine mastitis caused by different species of coagulasenegative

staphylococci identified with API or AFLP. Veterinary Microbiology. 115(1-3): 199207

24. Hogan, J. ; Pankey, J. (1987). Staphylococcus Species Other than Staphylococcus aureus. In: Proceedings of National Mastitis Council, 26th Ann Mtg, Orlando, Florida pp. 21.
25. Thorberg, B.M.; Kuhn, I.; Aarestrup, F.M.; Brandstrom, B.; Jonsson, P. \& DanielssonTham, M.L. (2006). Phenoand genotyping of Staphylococcus epidermidis isolated from bovine milk and human skin. Veterinary Microbiology 115(1-3): 16372.

26. De Vliegher, S.; Laevens, H.; Devriese, L.A.; Opsomer, G.; Leroy, J.L.; Barkema, H.W. \& de Kruif, A. (2003). Prepartum teat apex colonization with Staphylococcus chromogenes in dairy heifers is associated with low somatic cell count in early lactation. Veterinary Microbiology 92(3), 245-52

27. Matos, J.S.; White, D.G. ; Harmon, R.J. and Langlois. B.E. (1991): Isolation of Staphylococcus aureus from sites other than lactating mammary gland. J. Dairy Sci.74:1544.

28. International Mastitis Conference. (1995). Bovine mastitis. Document No. 132. Int. Mast. Con. Brussds, Belgium.

29. Costa, E.O.; Benites, N.R.; Guerra, J.L.; Melville, P.A. (2000). Antimicrobial susceptibility of Staph. spp. isolated from mammary parenchymas of slaughtered dairy cows. J. Vet. Med. B. Infect. Dis. Vet. Public. Health , 47(2): 99103.

30. Al-Dulimy,W.A.(2004). Study on Some Aerobic Bacterial Causes of Clinical Mastitis in Cows \& the Causes of some Treatment Failure. Thesis. M.S.C. Vet. Med. College. Baghdad University.

31.Zora, K.T.(1979). Some Studies on Clinical and Bacteriological Aspects of bovine mastitis 
.M.S.C. thesis .Vet.Med. College.Baghdad university.

32. Al-Graibawi, M. A.; Hassan, I. Q. and Yousif, A. A. (2002). Intramammary and systemic antibiotic therapy of bacterial clinical mastitis in cows. Iraq. J. Vet. Medi., 26(2): 153160.

33. Majeed , H.M.(2007):Isolation and Identification Some Caustive Agent Bacteria Cause Mastitis of Cow and the Role Of Lactobacillus in Inhibition Staphylococcus aureus. M.S.C. thesis . collage of Veterinary Medicine - University of Baghdad. Baghdad .Iraq.

34. Barañski W., Ra. M.; Janowski T.; Zduñczyk S.; Dewulf J.; De Kruif A.; De Vliegher S., Opsomer G.(2008): Udder pathogens isolated from milk of cows before drying off and their antibiotic sensitivity. Medycyna Wet. 64 (3).
35. Vink, D.(1995): Nile Delta A Cross-Sectional Study. P.H.D. thesis . Faculty of Veterinary Medicine University of Utrecht.Cairo, Egypt.

36. Hawari A. D.and Al-Dabbas F. (2008): Prevalence and Distribution of Mastitis Pathogens and their Resistance Against Antimicrobial Agents in Dairy Cows in Jordan. American J. Animal \& Vet. Sci., 3 (1): 36-39.

37. Mohsenzadeh, $M$ and Fallah Rad,A. H.( 2007): prevalence of and Antibiotic Susceptibility of CNS isolated from Bovine Intramammary Infection in Mashhad ,Iran .Journal of Animal and Veterinary Advances 6(8): 981-985.

38. Bennett, P.N. and Browen, M.J. (2003). pharmacology. $\quad 9^{\text {th }}$ Ed. Churchill. Livingstone. P:208-209.

\section{العزل والتشخيص ألمختبري لجراثيم المكورات العنقودية المسببة

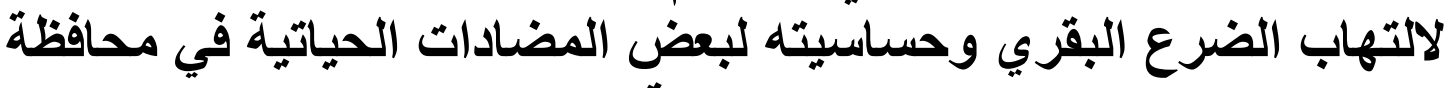 القادسبة لهية

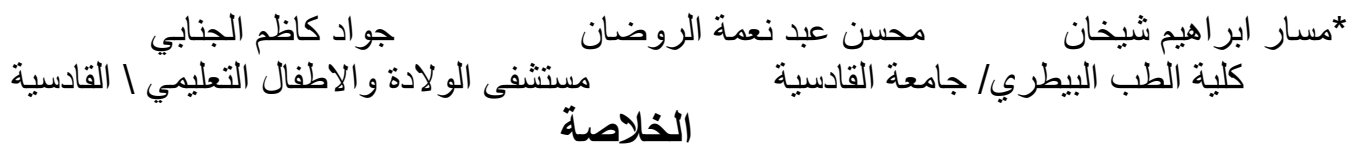

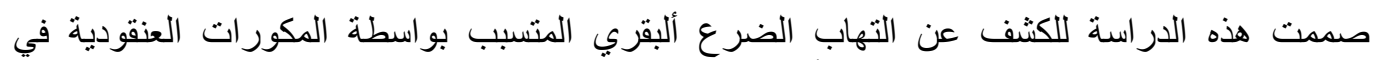

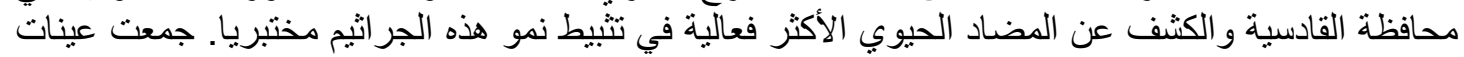

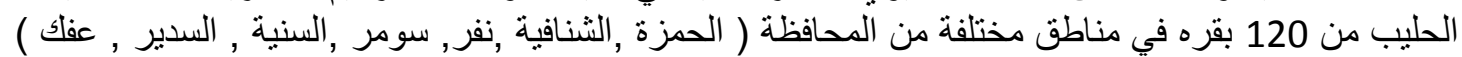

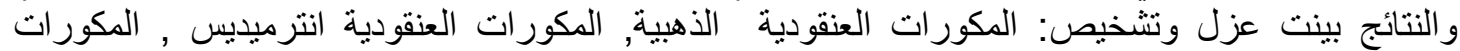

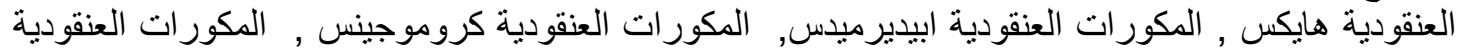

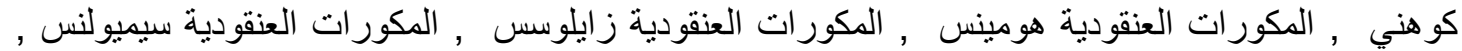

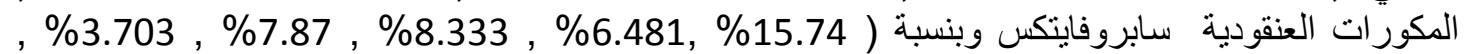

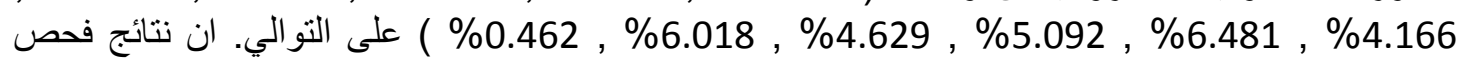

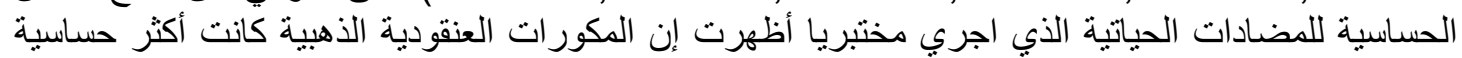

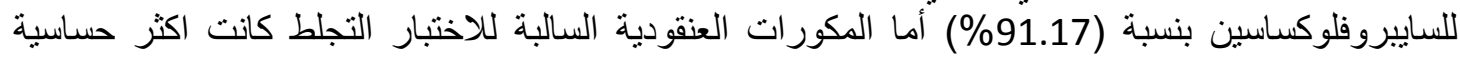

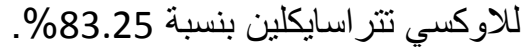

